\title{
Molecular Phylogenetic Diversity and Biological Characterization of Diaporthe Species Associated with Leaf Spots of Camellia sinensis in Taiwan
}

\author{
Hiran A. Ariyawansa ${ }^{1, *,+}+\mathbb{D}$, Ichen Tsai ${ }^{1,2,3,+}$, Jian-Yuan Wang ${ }^{1}$, Patchareeya Withee ${ }^{4}$, Medsaii Tanjira ${ }^{4}$, \\ Shiou-Ruei Lin ${ }^{5}$, Nakarin Suwannarach ${ }^{6,7}$ (D), Jaturong Kumla ${ }^{6,7}$ (D), Abdallah M. Elgorban ${ }^{8}$ (D) \\ and Ratchadawan Cheewangkoon $4,7, *$
}

check for updates

Citation: Ariyawansa, H.A.; Tsai, I.;

Wang, J.-Y.; Withee, P.; Tanjira, M.;

Lin, S.-R.; Suwannarach, N.; Kumla,

J.; Elgorban, A.M.; Cheewangkoon, R.

Molecular Phylogenetic Diversity and

Biological Characterization of

Diaporthe Species Associated with

Leaf Spots of Camellia sinensis in

Taiwan. Plants 2021, 10, 1434.

https://doi.org/10.3390/

plants10071434

Academic Editors: Milan S. Stankovic, Paula Baptista and Petronia Carillo

Received: 28 June 2021

Accepted: 12 July 2021

Published: 14 July 2021

Publisher's Note: MDPI stays neutral with regard to jurisdictional claims in published maps and institutional affiliations.

Copyright: (c) 2021 by the authors. Licensee MDPI, Basel, Switzerland. This article is an open access article distributed under the terms and conditions of the Creative Commons Attribution (CC BY) license (https:/ / creativecommons.org/licenses/by/ $4.0 /)$.
1 Department of Plant Pathology and Microbiology, College of Bioresources and Agriculture, National Taiwan University, Taipei 10617, Taiwan; ichenntsaii@gmail.com (I.T.); r07633020@gmail.com (J.-Y.W.)

2 Biodiversity and Climate Research Centre (BiK-F), 60325 Frankfurt am Main, Germany

3 Department of Biological Science, Goethe University Frankfurt, 60438 Frankfurt am Main, Germany

4 Department of Entomology and Plant Pathology, Faculty of Agriculture, Chiang Mai University, Chiang Mai 50200, Thailand; pwithee92@gmail.com (P.W.); t_medsaii@hotmail.com (M.T.)

5 Department of Tea Agronomy, Tea Research and Extension Station, Taoyuan 32654, Taiwan; tres226@ttes.gov.tw

6 Research Centre of Microbial Diversity and Sustainable Utilization, Faculty of Science, Chiang Mai University, Chiang Mai 50200, Thailand; suwan.462@gmail.com (N.S.); jaturong_yai@hotmail.com (J.K.)

7 Innovative Agriculture Research Center, Faculty of Agriculture, Chiang Mai University, Chiang Mai 50200, Thailand

8 Department of Botany and Microbiology, College of Science, King Saud University, Riyadh 11451, Saudi Arabia; aelgorban@ksu.edu.sa

* Correspondence: ariyawansa44@ntu.edu.tw (H.A.A.); ratchadawan.c@cmu.ac.th (R.C.)

+ H.A.A. and I.T. contributed equally to this study.

Abstract: Camellia sinensis is one of the major crops grown in Taiwan and has been widely cultivated around the island. Tea leaves are prone to various fungal infections, and leaf spot is considered one of the major diseases in Taiwan tea fields. As part of a survey on fungal species causing leaf spots on tea leaves in Taiwan, 19 fungal strains morphologically similar to the genus Diaporthe were collected. ITS (internal transcribed spacer), tef1- $\alpha$ (translation elongation factor $1-\alpha$ ), tub2 (beta-tubulin), and cal (calmodulin) gene regions were used to construct phylogenetic trees and determine the evolutionary relationships among the collected strains. In total, six Diaporthe species, including one new species, Diaporthe hsinchuensis, were identified as linked with leaf spot of $C$. sinensis in Taiwan based on both phenotypic characters and phylogeny. These species were further characterized in terms of their pathogenicity, temperature, and $\mathrm{pH}$ requirements under laboratory conditions. Diaporthe tulliensis, $D$. passiflorae, and D. perseae were isolated from C. sinensis for the first time. Furthermore, pathogenicity tests revealed that, with wound inoculation, only D. hongkongensis was pathogenic on tea leaves. This investigation delivers the first assessment of Diaporthe taxa related to leaf spots on tea in Taiwan.

Keywords: endophytes; foliar pathogens; pathogenicity; taxonomy

\section{Introduction}

Species of Diaporthe have been frequently reported as pathogens, endophytes, and saprobes of various types of hosts [1-17]. These taxa have been reported globally and cause various diseases on economically important plants and crops such as dieback of forest trees [2], leaf spots on tea and Ixora spp. [3,4], leaf and pod blights and seed decay in soybean [5], melanose and stem-end rot on Citrus spp. [6-10], leaf spot on common hop [11], twig blight and dieback of blueberry [12], trunk diseases of grapevines [13], branch canker 
on Cinnamomum camphora (Camphor Tree) [14], pear shoot canker [15], and stem canker on sunflower $[16,17]$.

The genus Diaporthe (syn. Phomopsis) was introduced by Nitschke and is typified by $D$. eres [18-27]. It is categorized in the family Diaporthaceae and order Diaporthales [18-27]. The holomorphic name for Diaporthe/Phomopsis was complex. Therefore, following the nomenclature rules, Rossman et al. [28] recommended adopting the older sexual typified name Diaporthe over the younger asexual typified name Phomopsis. Currently, Index Fungorum (retrieved in April 2021) reported over 900 names under the genus Phomopsis, whereas Diaporthe contains over 1000 names. Species of Diaporthe were traditionally identified based on their phenotypic characters such as colony morphology, appearance of ascomata and conidiomata, variation in ascospores and conidiospores, and host affiliations [18-27]. However, due to improvements in DNA sequencing, various enigmatic taxa have been discovered, which has reformed our understanding of the natural classification of Diaporthe. Recent studies based on molecular phylogeny have continuously discovered that traditionally used morphological characters and host associations are not sufficient to determine the species of Diaporthe strains because they show variation under different environmental conditions [29]. Therefore, multilocus phylogenies based on DNA sequences of ITS (internal transcribed spacer), tef1- $\alpha$ (translation elongation factor 1- $\alpha$ ), tub2 (beta-tubulin), and cal (calmodulin) are more often used to determine the natural classification of Diaporthe species [1,26,29-31].

Foliar fungal pathogens that infect Camellia sinensis can lead to a notable reduction in their yield, resulting in a loss of income $[3,32,33]$. Tea leaves at all stages are susceptible to fungal diseases $[3,32,33]$. In total, 520 fungal species have been identified to occur on Camellia species, of which 303 were reported from C. sinensis according to the U.S. Department of Agriculture (USDA) database [3,4]. Various fungi are known to cause diseases of leaves, stems, and roots of $C$. sinensis and other Camellia species, for example, brown blight caused by Colletotrichum species, gray blight by Pestalotiopsis-like taxa, leaf spots and dieback by Diaporthe species, and blister blight by Exobasidium vexans $[3,32,33]$. Our research group studies various foliar diseases allied with tea farms in Taiwan $[32,33]$. Our previous work has indicated that in addition to the major fungal diseases, such as brown blight due to Colletotrichum species complex and grey blight disease caused by Pestalotiopsis-like taxa, numerous other fungal species can potentially cause leaf spots on C. sinensis in Taiwan $[32,33]$. Therefore, the aim of this study was to fully characterize the diversity and phylogeny of Diaporthe-like strains originally isolated from the leaf spots of $C$. sinensis and evaluate their pathogenicity to the major tea cultivar Chin-Shin Oolong grown in Taiwan's tea fields. This study was conducted to obtain a better understanding of pathogen biology and determine the optimal temperature and $\mathrm{pH}$ for the mycelial growth of these fungi under laboratory conditions.

\section{Results}

\subsection{Fungal Isolation}

In total, 19 Diaporthe-like strains associated with leaf spots of $C$. sinensis were isolated from five different tea fields located in Taiwan (Figure 1 and Table S1).

\subsection{Phylogenetic Evaluation of the Concatenated Data Matrix of Diaporthe Species}

Prior to the multilocus gene analysis, alignments corresponding to the gene regions of ITS, tef1- $\alpha, t u b 2$, and $c a l$ were analyzed using ML. Congruence between single loci made it conceivable to evaluate the phylogenies by concatenating the genes as it delivered a guarantee of gene orthology. The phylogenetic tree obtained from the concatenated gene datasets is in Figure 2. 


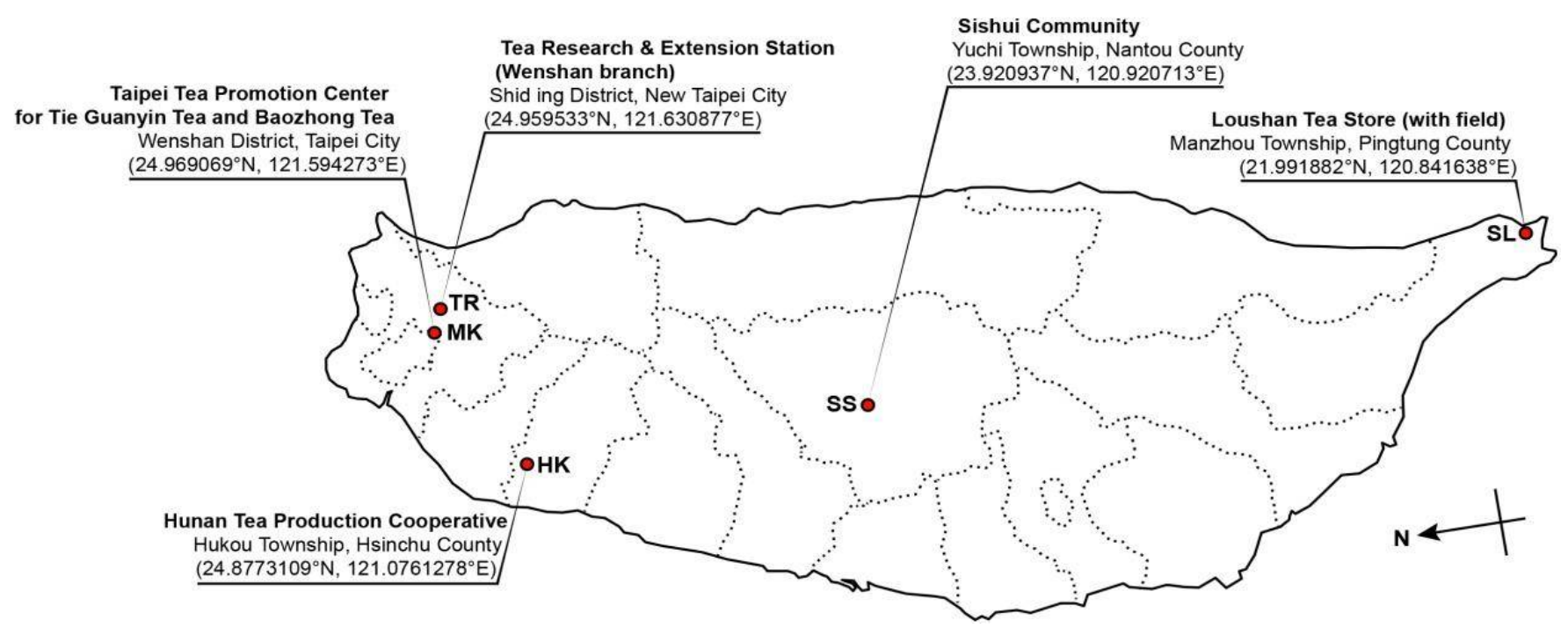

Figure 1. Tea fields surveyed in this study. Relevant geographical details are given for each indicated location.

The final phylogenetic tree was inferred using the combined gene data matrix of ITS, tef1- $\alpha, t u b 2$, and cal gene regions from 244 strains of Diaporthe species and Diaporthella corylina CBS 121124 as the outgroup taxon. The final combined data matrix contained 1803 characters, including gaps (624 for ITS, 526 for $c a l, 381$ for $t u b 2$, and 272 for tef1- $\alpha$ ). The following priors were used in MrBayes for the five gene loci data partitions based on the results of MrModeltest: all partitions had Dirichlet base frequencies and GTR + I + G models with inverse gamma-distributed rates implemented for ITS and tub2, and HKY + I $+\mathrm{G}$ with inverse gamma-distributed rates for $c a l$ and tef1- $\alpha$. The Bayesian analysis resulted in 90,000 trees after $90,000,000$ generations. The first $20 \%$ of trees representing the burn-in phase of the analyses were discarded, while the remaining trees were used to calculate Bayesian posterior probabilities (PP) in the majority rule consensus tree. The best scoring RAxML tree had a likelihood value of: -4812.054120 and GTR + I + G was used as the evolutionary model.

The phylogenetic trees obtained from both ML and Bayesian analyses had a similar topology and branching pattern based on phenotypic characters and were supported by the molecular phylogenetic inference of strains generated in this study. The results were consistent with recent publications [3,12,13,30,34-36]. In the present phylogeny (Figure 2), out of 19 strains, 16 were assigned to previously described species, namely, D. apiculatum (4), D. hongkongensis (4), D. tulliensis (3), D. passiflorae (2), and D. perseae (3). Three strains in this study formed distinct clades with a highly supported sub-clade, which was identified as a novel species and named $D$. hsinchuensis. 


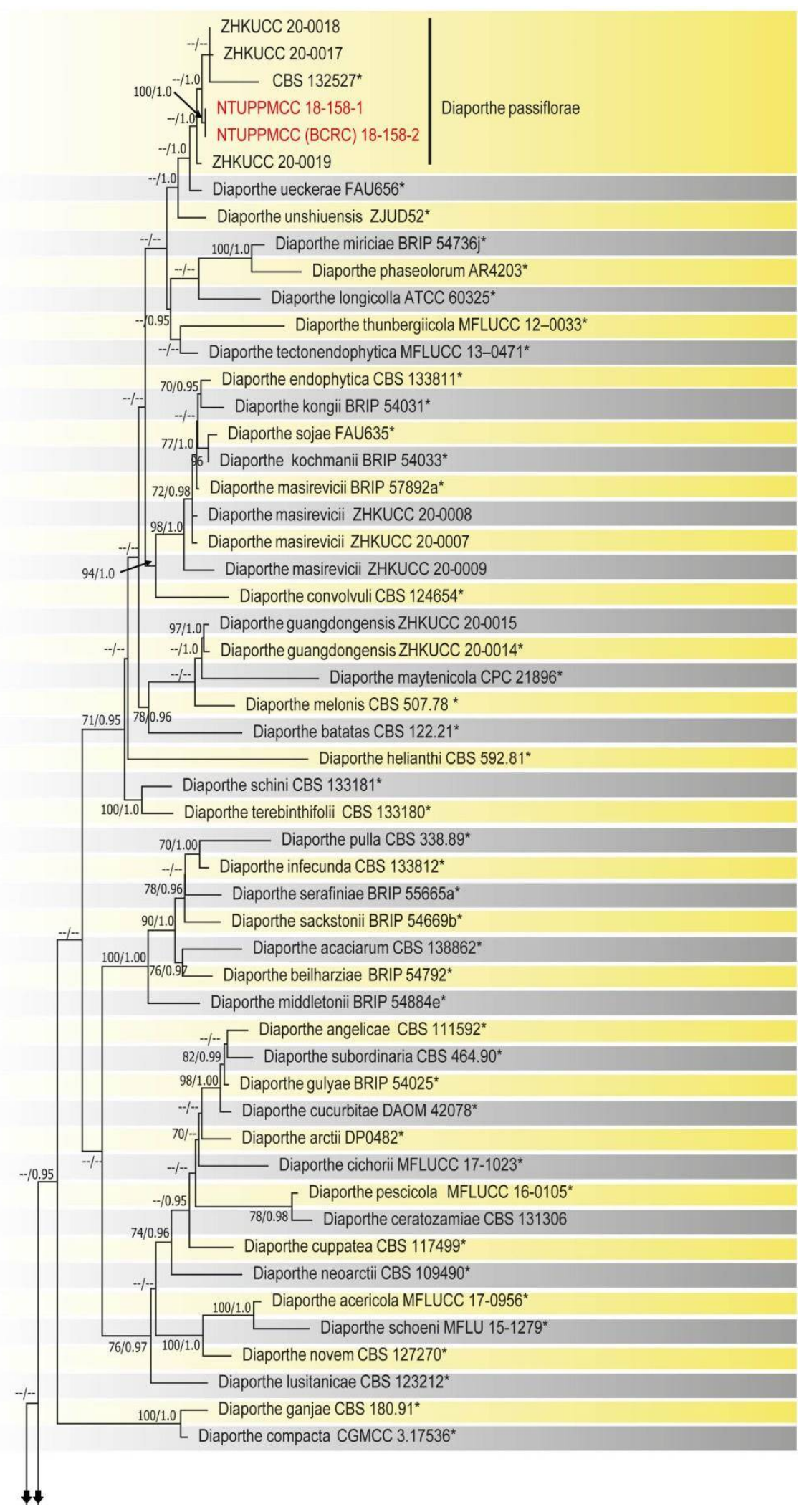

Figure 2. Cont. 


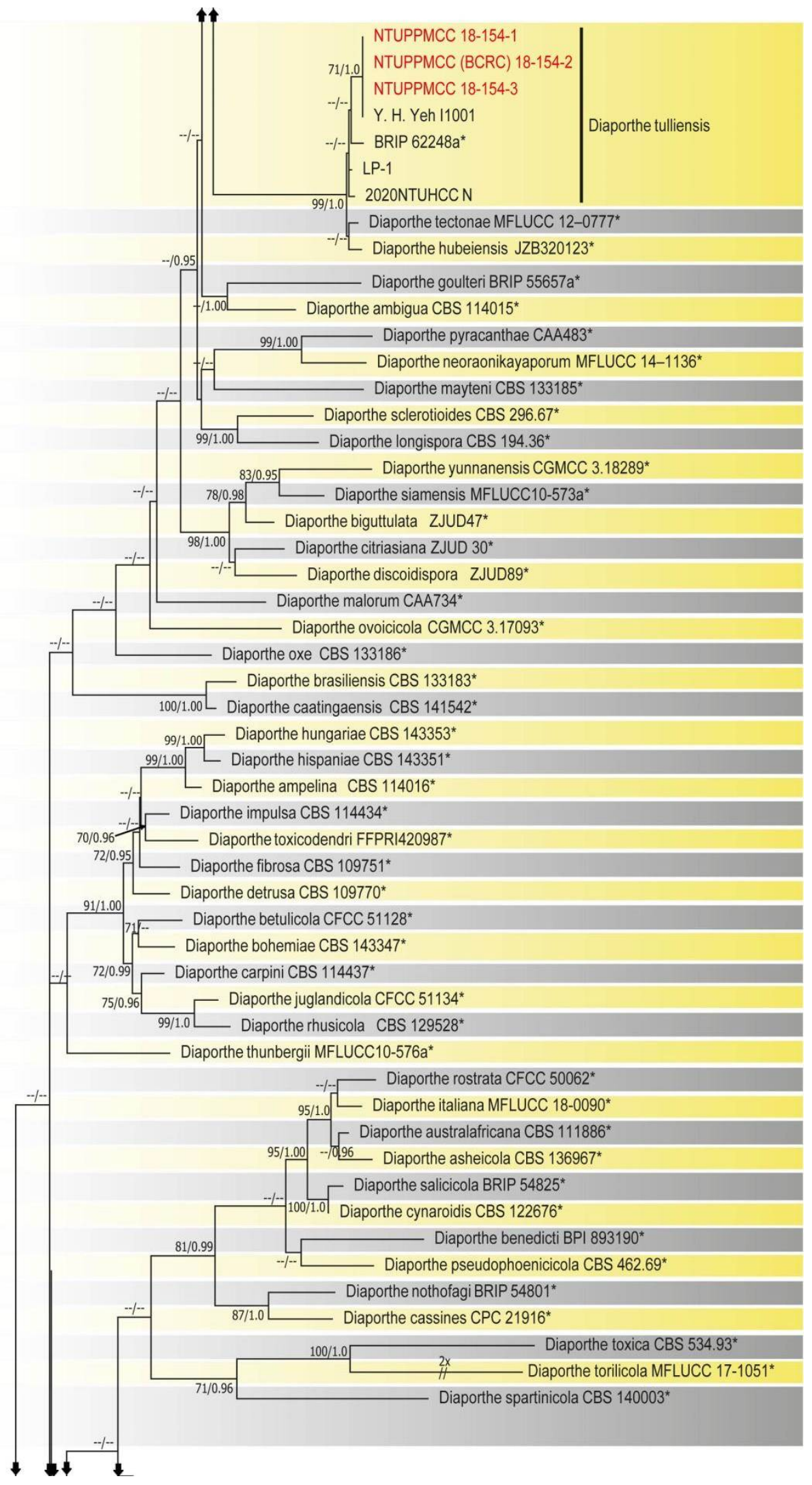

Figure 2. Cont. 


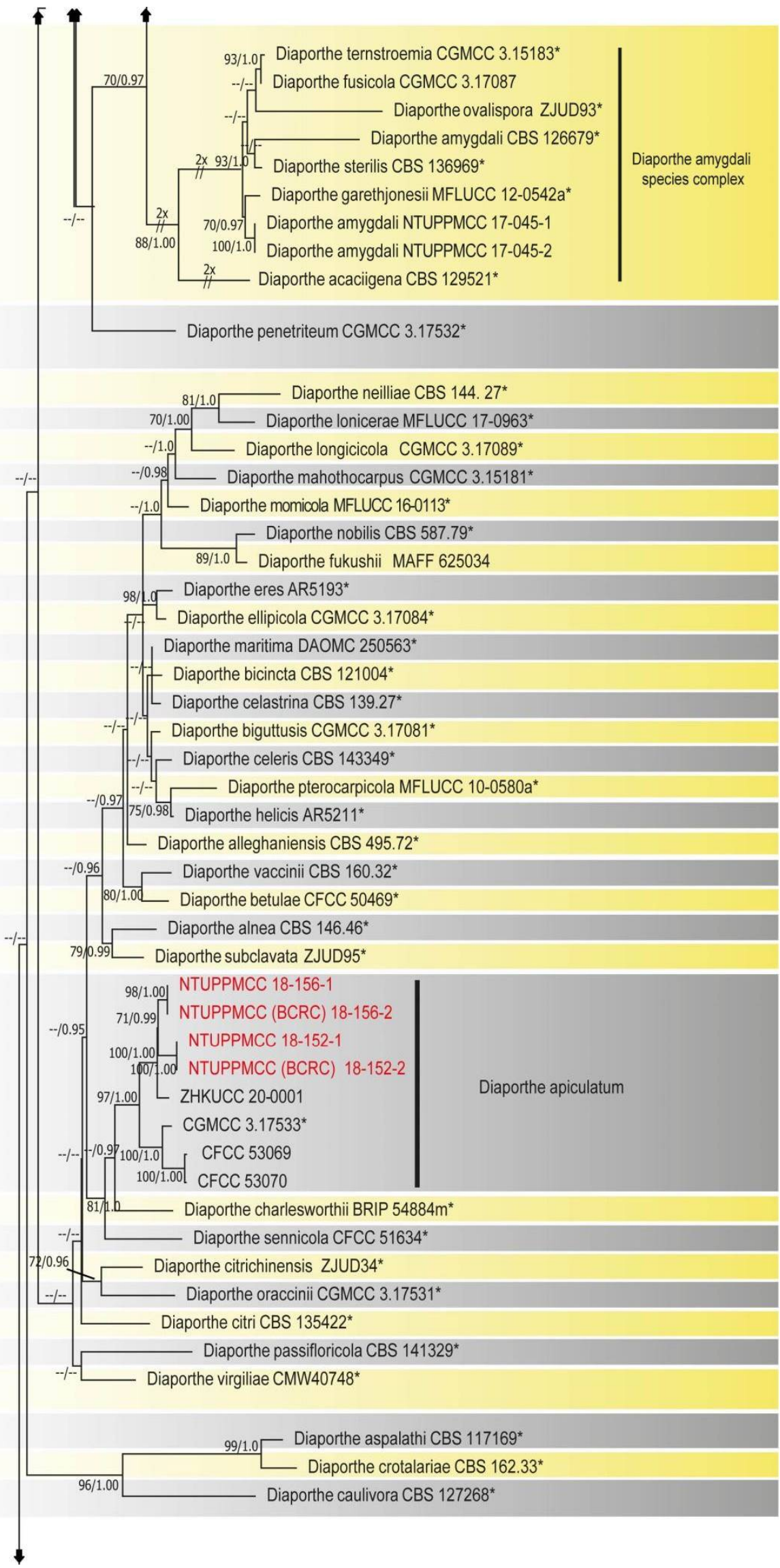

Figure 2. Cont. 


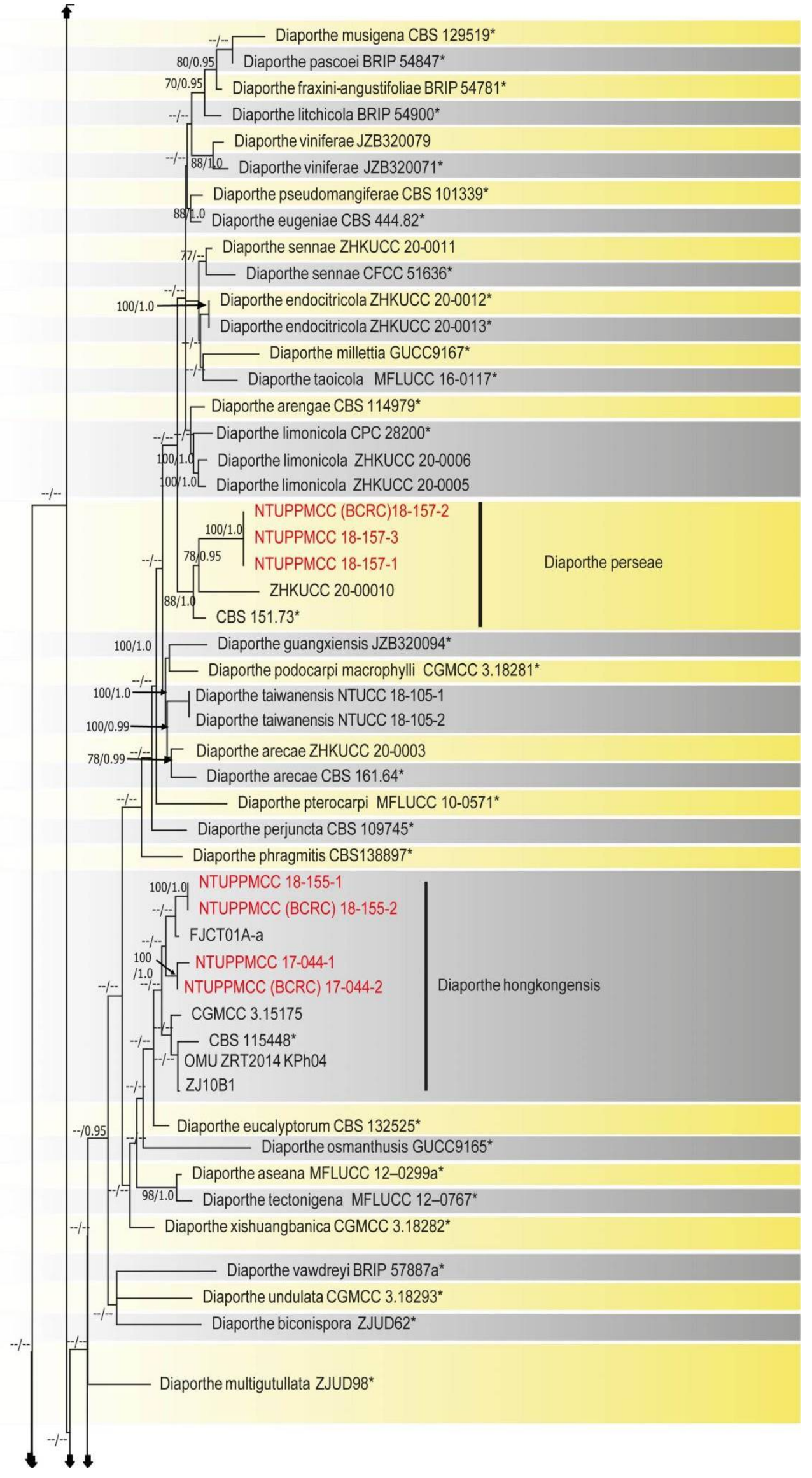

Figure 2. Cont. 


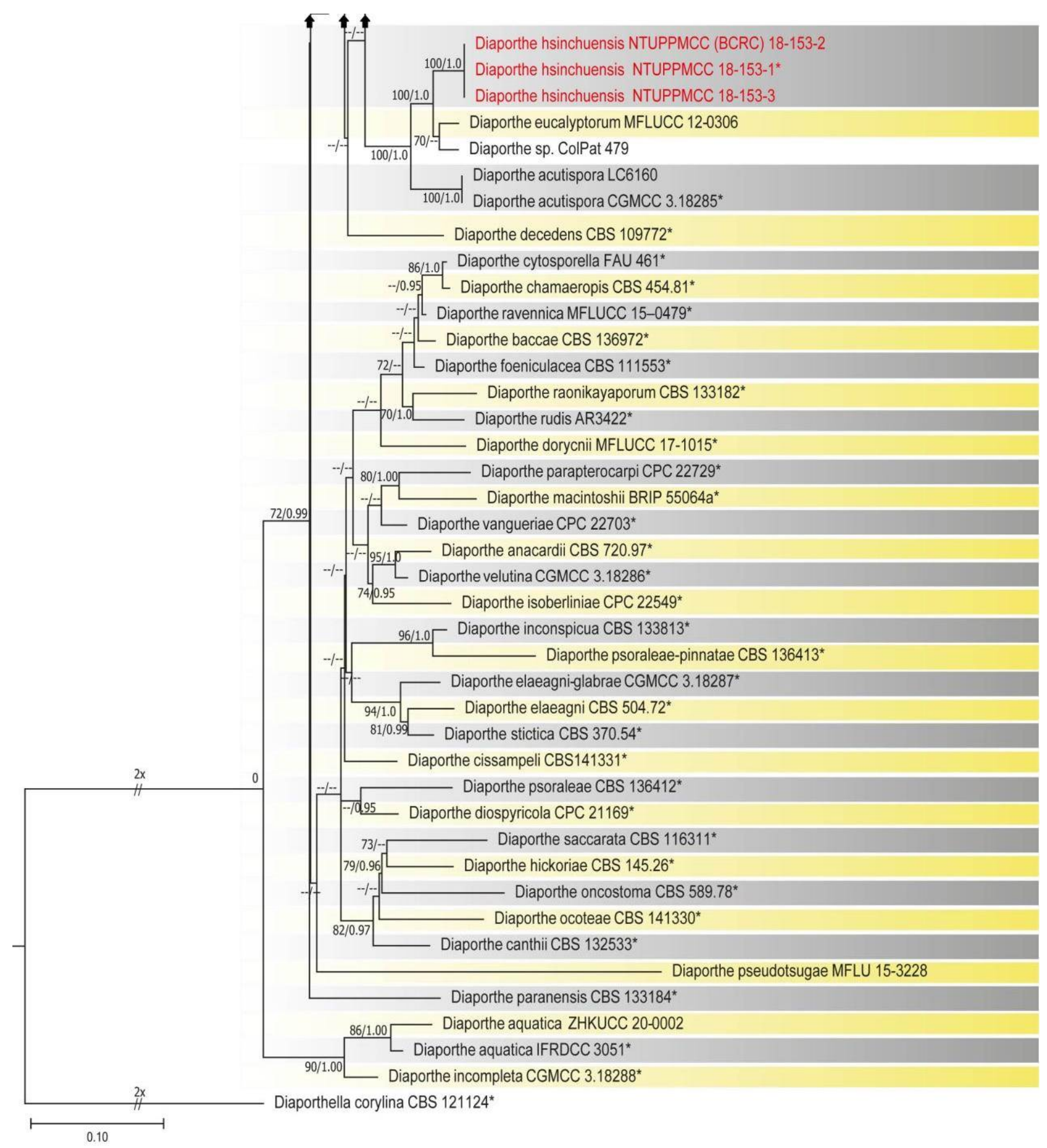

Figure 2. Phylogenetic tree of Diaporthe generated from a combined sequence dataset of ITS, tef1- $\alpha$, tub2, and cal gene regions. Bootstrap values greater than $70 \%$ and Bayesian posterior probabilities greater than 0.95 were given below or above the nodes. Isolates obtained in this study are indicated in red, and the ex-type sequences are indicated by *. The strain codes were annotated after relevant species names. Diaporthella corylina CBS 121124 served as an outgroup taxon.

2.3. Taxonomy Diaporthe hsinchuensis Ariyawansa and I. Tsai, sp. nov.

MycoBank: MB840098, Figure 3 

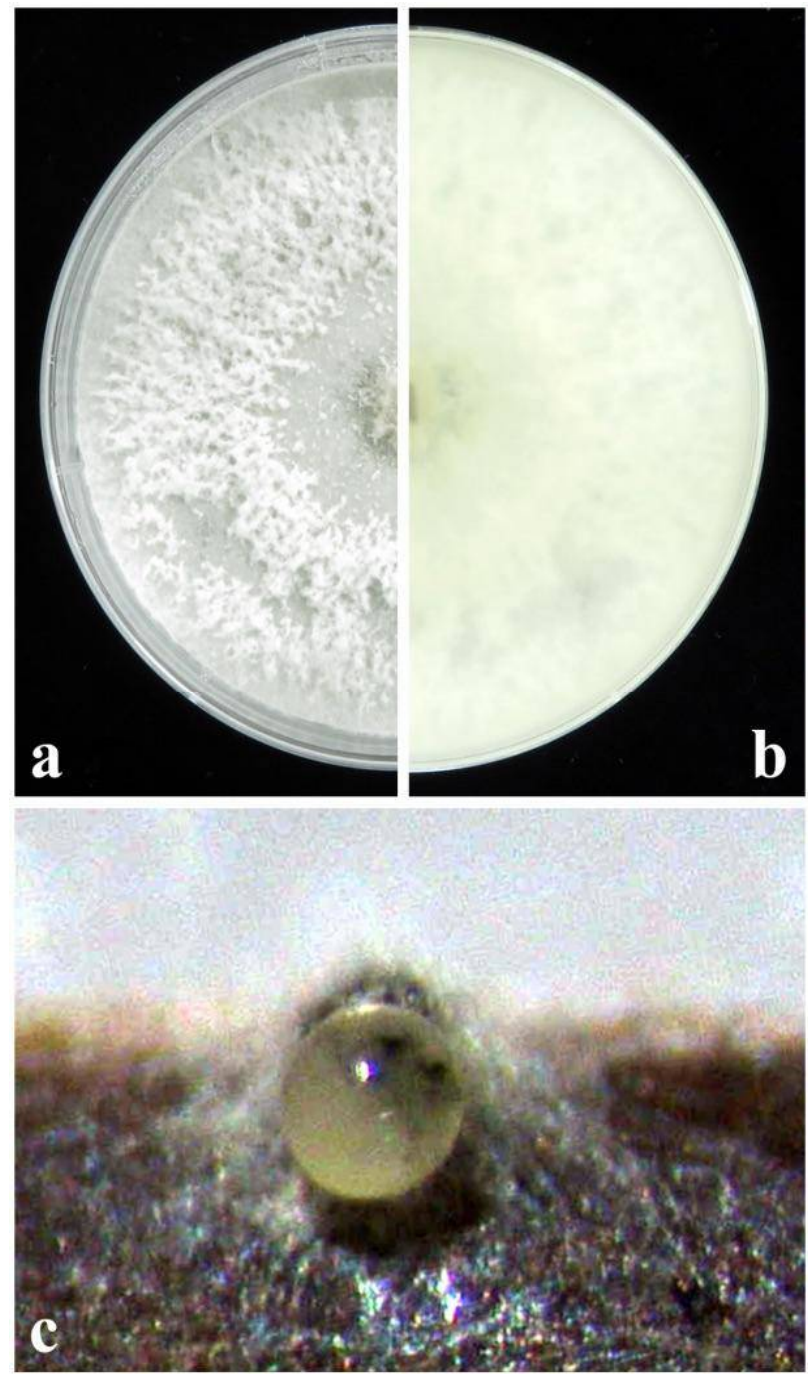
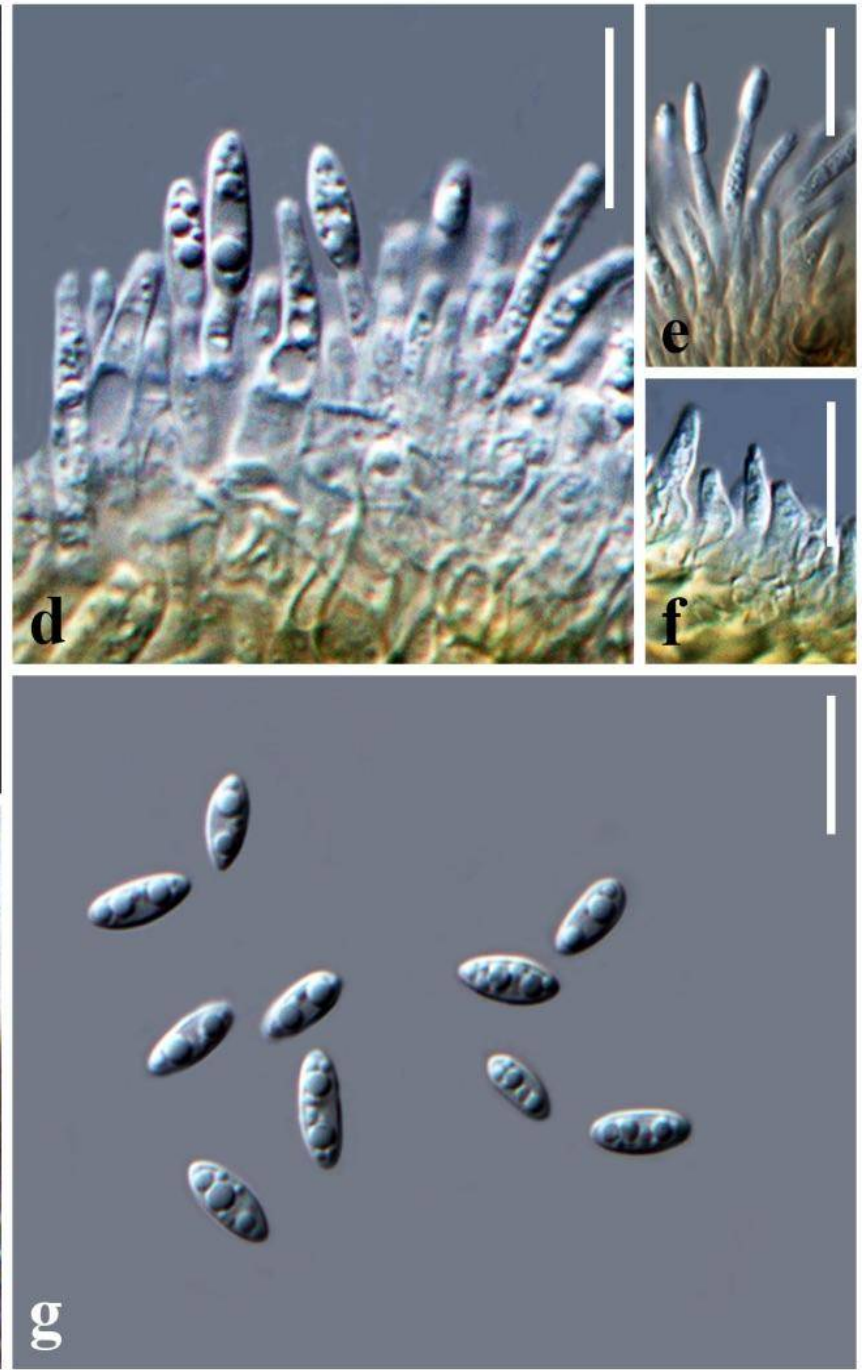

Figure 3. Diaporthe hsinchuensis NTUPPMCC 18-153-1: (a,b) surface and reverse side of colony on PDA; (c) conidiomata on PNA. (d-f); conidiogenous cells; (g) conidia. Scale bars $=10 \mu \mathrm{m}$.

Etymology: The epithet refers to Hsinchu, Taiwan, where this species was originally collected.

Description: Forms grey lesions on the tip of the tea (Camellia sinensis) leaf. Sexual morph: Undetermined. Asexual morph: Conidiomata pycnidial on PNA, globose, erumpent when mature, conidia exuding from the pycnidia in ivory white drops. Conidiophores cylindrical, phialidic, septate, and branched, $8-20 \times 1-3 \mu \mathrm{m}(\bar{x} \pm \mathrm{SD}=14.1 \pm 2.9 \times 2.0$ $\pm 0.4 \mu \mathrm{m}, \mathrm{n}=30$ ). Alpha conidiogenous cells hyaline, ovoid to ampulliform, cylindrical to subcylindrical tapering towards the apex, straight or curved, $1-8 \times 1-4 \mu \mathrm{m}(\bar{x} \pm \mathrm{SD}=5.6$ $\pm 1.9 \times 2.4 \pm 0.6 \mu \mathrm{m}, \mathrm{n}=30$ ). Alpha conidia hyaline, oval, or fusiform, unicellular, aseptate, 2-7-guttulate 6-9 $\times 2.5-4 \mu \mathrm{m}(\bar{x} \pm \mathrm{SD}=7.5 \pm 0.9 \times 3.2 \pm 0.2 \mu \mathrm{m}, \mathrm{n}=30)$. Beta conidia not observed. Gamma conidia not observed.

Colony characteristics: Colonies on PDA circular, edge entire, surface white, cottony, reverse yellowish white. 
Material examination: Taiwan, Hsinchu County, Hukou Township, Hunan Tea Production Cooperative, on leaves of Camellia sinensis (Theaceae), 4 April 2018, Tsai Ichen, HK04-1 (NTUPPMH 18-153-1, holotype), ex-type culture NTUPPMCC 18-153-1; ibid., HK04-2 (NTUPPMH 18-153-2) = living culture NTUPPMCC 18-153-2.

Notes: The strains representing Diaporthe hsinchuensis clustered in a well-supported clade $(\mathrm{ML} / \mathrm{PP}=100 / 1.0)$ and formed a distinct linage sister to D. eucalyptorum (MFLUCC 12-0306), D. acutispora (LC6160 and LC6161), and Diaporthe sp. (ColPat479) (Figure 2). Unfortunately, morphological data were not available for D. eucalyptorum (MFLUCC 120306) or Diaporthe sp. (ColPat479). Furthermore, the ex-type strain of D. eucalyptorum (CBS 132525), which was used by Crous et al. [37] to introduce the species, appeared as a basal clade to strains containing $D$. hongkongensis in the present study in agreement with previous studies $[2,30]$. This may indicate that D. eucalyptorum (MFLUCC 12-0306), used by Senanayake et al. [38], is a different species, but further studies are required to confirm the taxonomic status of this strain. Based on the available data, we only compared the morphological features of $D$. hsinchuensis with $D$. acutispora. D. hsinchuensis differs from $D$. acutispora in its smaller conidiophores $(8-20 \times 1-3 \mu \mathrm{m}$ versus $10-34.5 \times 2-3 \mu \mathrm{m})$, relatively smaller alpha conidia $(6-9 \times 2.5-4 \mu \mathrm{m}$ versus $7-10 \times 2-3 \mu \mathrm{m})$, host (Camellia sinensis versus Coffea sp.), and geographical location (Taiwan versus China). In addition, D. hsinchuensis can be clearly differentiated based on nucleotide differences in ITS, tef1- $\alpha$, tub2, and cal loci from its phylogenetically closely related species, D. acutispora (ITS $4 \%$; tef1- $\alpha 14 \%$; tub2 5\%; cal 6\%).

\subsection{Growth Rate}

All tested isolates were grown on PDA media for 7 days at $25^{\circ} \mathrm{C}$ in the dark. The sizes of colonies were measured $(\mathrm{mm})$, and their means were calculated and are presented in Figure 4. Isolate NTUPPMCC 18-153-1 (D. hsinchuensis) exhibited the widest diameter colony (70.33 mm on average), which, along with isolate NTUPPMCC 18-154-1 (D. tulliensis), presented significantly faster growth after 7 days of incubation. In contrast, strain NTUPPMCC 18-152-1 (D. apiculatum), 18-155-1 (D. hongkongensis), and 18-157-1 (D. perseae) had significantly slower growth compared to all the other isolates.

\subsection{Temperature Effects}

Fungal mycelial growth was detected for all the tested isolates between 10 to $45^{\circ} \mathrm{C}$ and measured as colony diameter. Temperature regimes strongly influenced the growth of tested fungal strains $(p \leq 0.001)$; the maximum growth was determined at $25-30{ }^{\circ} \mathrm{C}$ (mean $60.39 \mathrm{~mm}$ ), while the minimum or no-growth was observed at $40-45^{\circ} \mathrm{C}$ (mean $0.10 \mathrm{~mm}$ ) for all the isolates (Figure 5, Table S2).

\subsection{Optimal $p H$}

The effects of $\mathrm{pH}$ on the mycelial growth of tested strains are presented in Figure 6 and Table S3. Results showed that, generally, all strains used in this study grow better in slightly acidic to alkaline medium ( $\mathrm{pH} 5-10)$ compared with acidic medium (pH 3-5). Isolates NTUPPMCC 18-153-1 and 18-155-1 showed a relatively narrower optical $\mathrm{pH}$ range ( $\mathrm{pH} 6-8$ and 5-7, respectively) upon mycelial growth compared with the other isolates. 


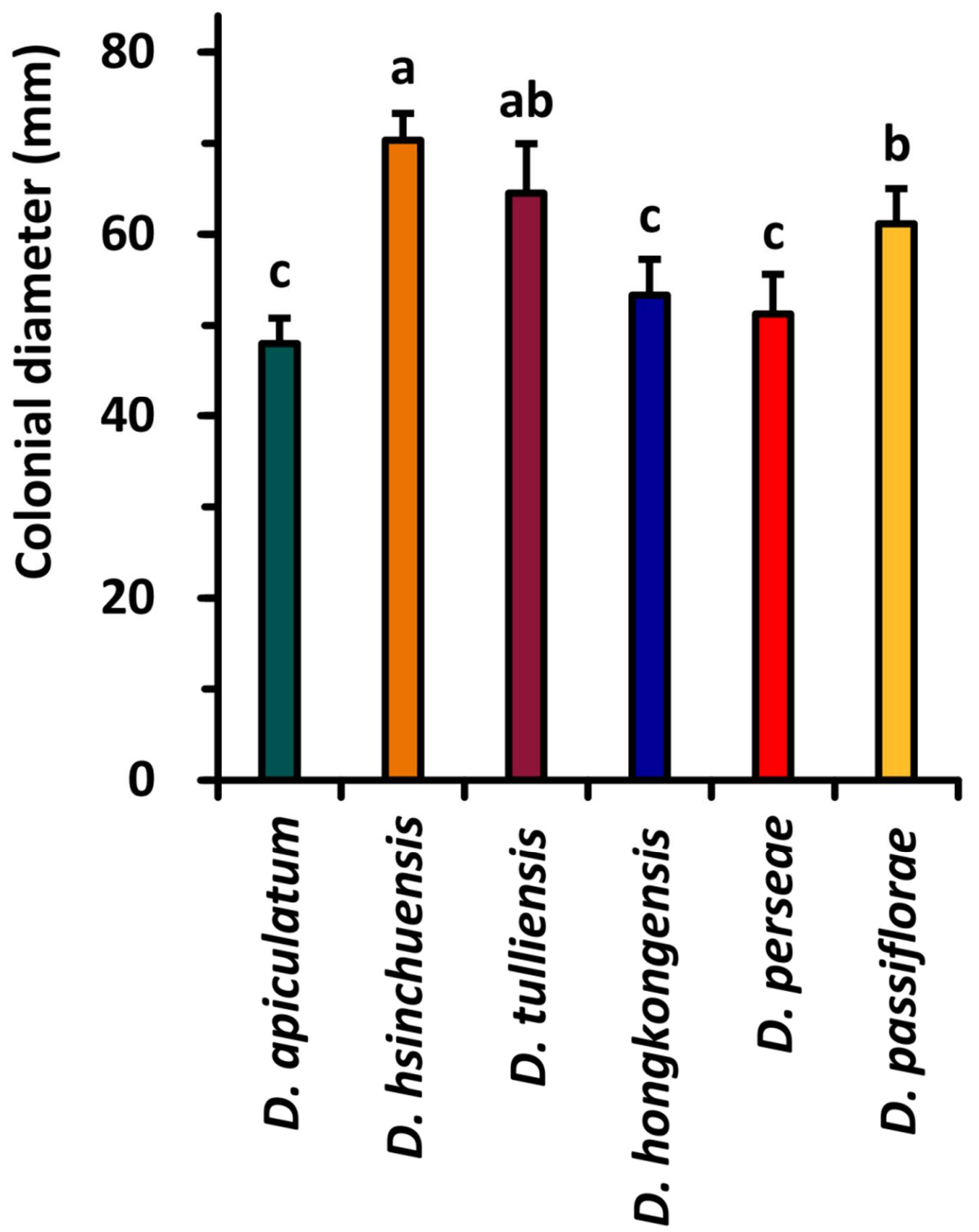

\section{Species}

Figure 4. Comparison of mycelial growth rate of the six Diaporthe species based on perpendicular colonial diameter. According to Tukey's range test, data (mean \pm standard deviation) with the same letters are not significantly different. Colors identify different taxa.

\subsection{Pathogenicity}

In total, all six selected isolates except NTUPPMCC 18-155-1 (D. hongkongensis) failed to cause symptoms on either wounded or unwounded inoculated sites. However, NTUPPMCC 18-155-1 caused symptoms on wounded inoculated sites on tea leaves (Figure 7), showing that the strain might enter tea leaves via wounds. The characteristic of the concentric circular fruiting-body formation and brown blight shared among observed symptoms (Figure $7 \mathrm{~d}$ ) were consistent with that observed in natural tea fields. The fungal strain capable of forming lesions on wounds in this experiment was re-isolated from the fruiting lesions with morphological characteristics identical to those of the original isolates. 
Therefore, Koch's postulates were fulfilled and based on both the DNA sequence data and morphological evidence from these re-isolates, all were confirmed to be pathogenic to C. sinensis.

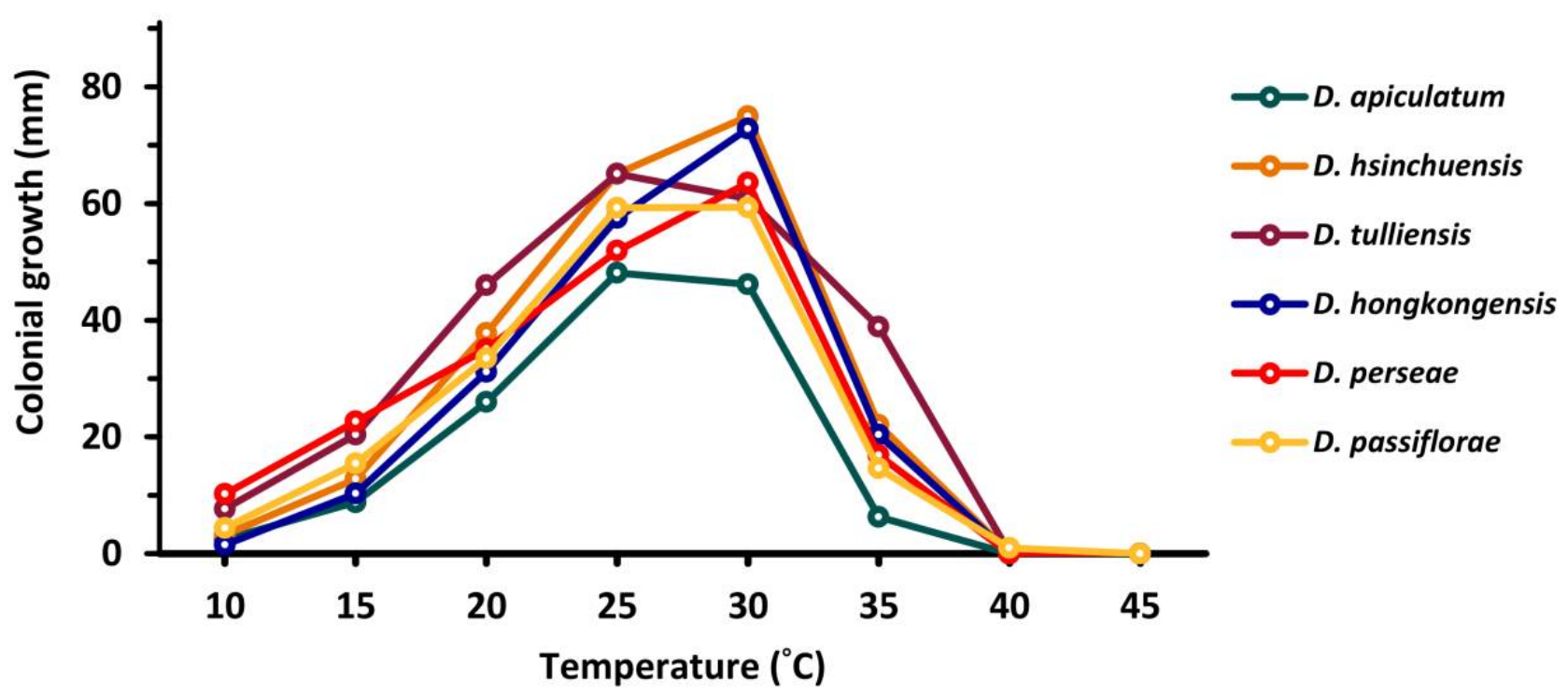

Figure 5. Temperature effect on mycelial growth according to the comparison of colonial growth (mm) of different species at each temperature, based on the mean values presented in Table S2.

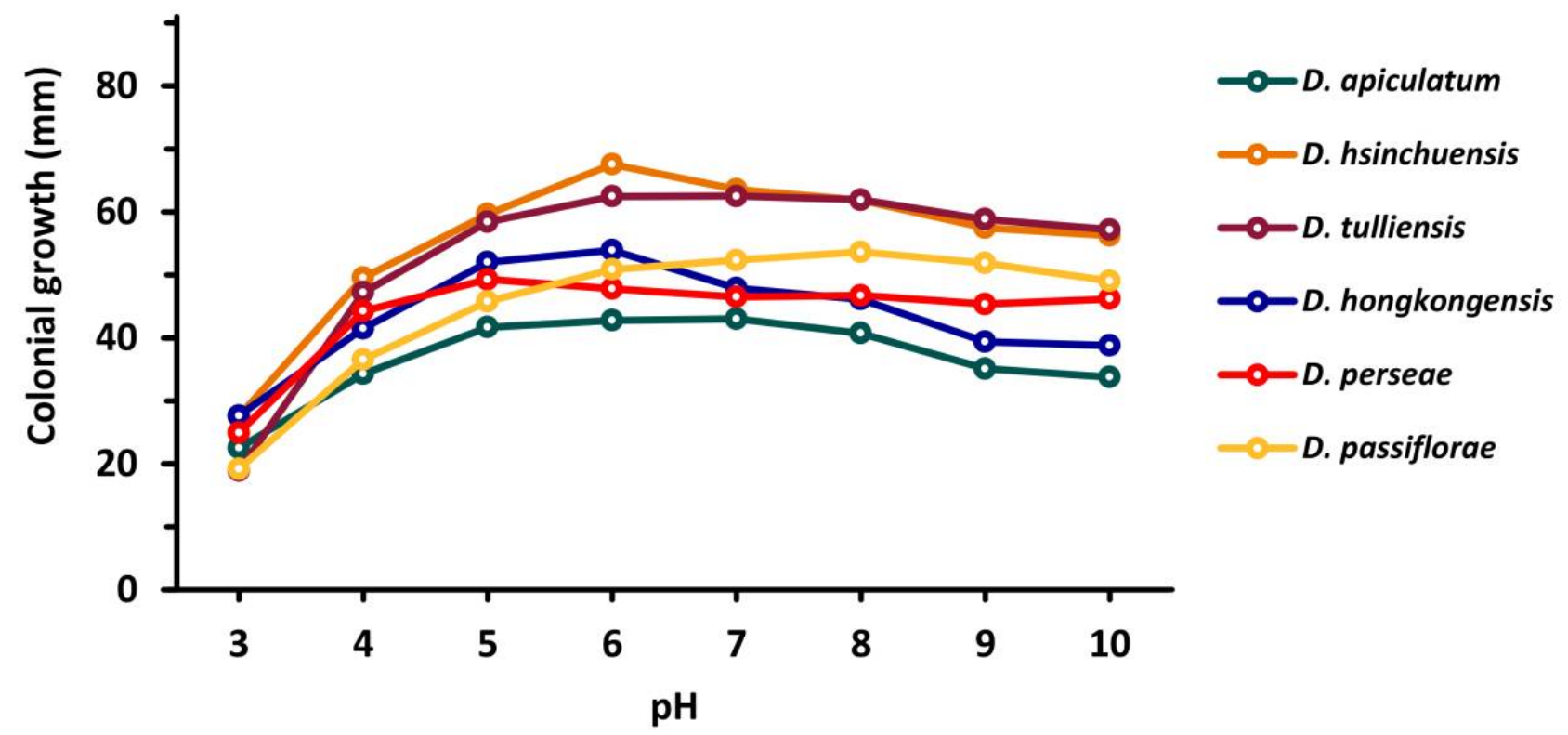

Figure 6. Optimal $\mathrm{pH}$ for mycelial growth of each species according to the comparison of colonial growth (mm diam), based on the mean values presented in Table S3. 

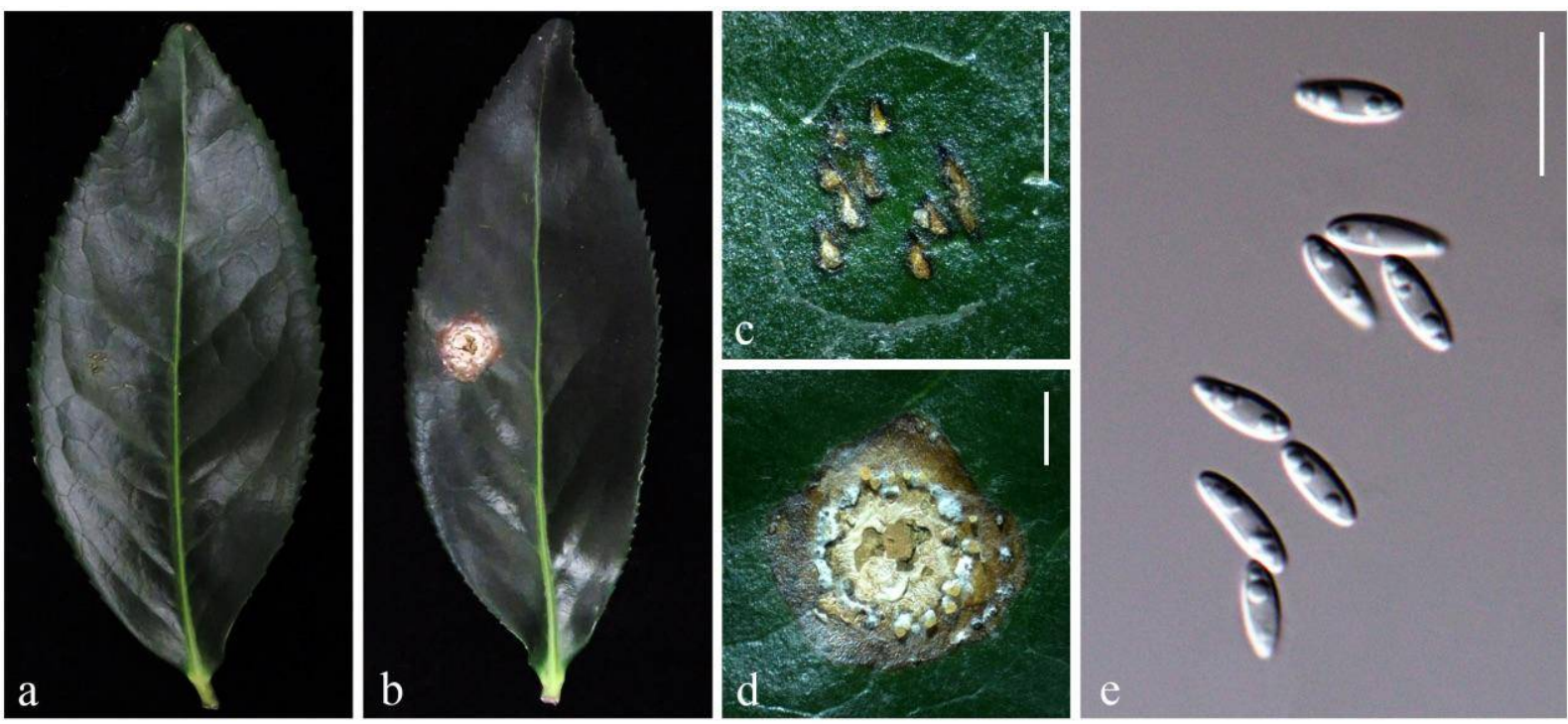

Figure 7. Symptoms caused by D. hongkongensis: (a,c) control leaf inoculated with PDA disk, symptoms absent; $(\mathbf{b}, \mathbf{d})$ symptom on tea leaf inoculated with $D$. hongkongensis 14 days after incubation (lesion size on average $=6.38 \mathrm{~mm}$ diam); (e) conidia obtained from artificially generated lesion. Scale bars: $(\mathbf{c}, \mathbf{d})=2 \mathrm{~mm} ;(\mathbf{e})=10 \mu \mathrm{m}$.

\section{Discussion}

Tea is one of the major crops grown in Taiwan, and oolong tea produced by Taiwan is responsible for $25 \%$ of global oolong production (One Town One Product (OTOP) [32,33]. Foliar diseases of $C$. sinensis are of concern to tea farmers because leaves are the main part of the plant used to produce various teas. However, research regarding Diaporthe species causing foliar diseases of $C$. sinensis is rare, and twig blight caused by unknown Phomopsis species (asexual morph of Diaporthe) are the only diseases caused by Diaporthe mentioned in the list of plant diseases in Taiwan [39].

Accurately naming a fungus based on its molecular and phenotype characters that reflect phylogeny allows predictions about plant-associated organisms together with potential pathogenicity and appropriate control measures. In the present study, we identified six Diaporthe taxa linked with leaf spot in Taiwan tea fields, including a novel species. Various Diaporthe species have been identified as either pathogens or endophytes on $C$. sinensis such as $D$. amygdali, D. apiculata, D. discoidispora, D. eres, D. foeniculacea, D. foeniculina, D. hongkongensis, D. incompleta, D. longicicola, D. masirevicii, D. nobilis, D. oraccinii, D. penetriteum, D. portugallica, D. tectonigena, D. ueckerae, D. velutina, and D. xishuangbanica [40]. Among the tested isolates, D. hongkongensis fulfilled Koch's postulates and was identified as the only pathogen causing leaf spot on $C$. sinensis in the present study. D. hongkongensis has been recognized as a well-known phytopathogen affecting various hosts such as grapevine [41], peach [42], kiwifruit [43], dragon fruit [44], and pear [15] in recent studies. D. hongkongensis was also reported to be associated with both healthy and diseased tea leaves in China by Gao et al. [3]. However, in their study, Gao et al. [3] did not confirm the pathogenicity of $D$. hongkongensis to tea leaves by fulfilling Koch's postulates. In addition, there is no record of $D$. hongkongensis causing plant diseases in Taiwan. Therefore, to the best of our understanding, this is not only the first report of $D$. hongkongensis causing leaf spot on $C$. sinensis, but also a novel discovery of $D$. hongkongensis present in Taiwan.

Furthermore, in this study, we reported another species associated with tea leaf spot, namely, D. apiculatum, for the first time in Taiwan. Gao et al. [3] introduced D. apiculatum as a new species from the healthy and infected leaves of $C$. sinensis in China but did not confirm the pathogenicity of the fungal strains via Koch's postulates. However, in the present study, strains that we identified as D. apiculatum did not fulfill Koch's postulates after 14 days of incubation. Therefore, further studies are required to confirm whether this 
is a latent pathogen or a conditional pathogen, causing symptoms when the plant defense mechanisms are weak.

In the present study, Diaporthe passiflorae, D. tulliensis, and D. perseae were isolated from the leaf spots of $C$. sinensis for the first time. D. passiflorae was introduced by Crous et al. [37] as a potential endophyte on the fruit of Passiflora edulis. In contrast, Li et al. [45] identified the same species as a postharvest pathogen causing fruit rot of Kiwifruit in Sichuan Province, China. D. perseae was originally described as Phomopsis perseae Zerova from branches of dying Persea gratissima trees in Russia [29]. This species also has been identified as a pathogen of mango causing fruit rot in Malaysia [46] and as endophytes on Citrus grandis in China [30]. D. tulliensis has been recognized as an important pathogen of various hosts, such as kiwifruit [47], coffee [48], and grapes [13]. Interestingly, Huang et al. [49] and Chen and Kirschner [50] recently reported the same species as a pathogen causing leaf spot on Parthenocissus tricuspidata as well as an endophyte from Nelumbo nucifera in Taiwan, respectively. However, in the present study, none of the strains recognized as D. passiflorae, $D$. perseae, D. tulliensis, or the new species $D$. hsinchuensis, satisfied Koch's postulates after 14 days of incubation. Thus, they were not considered pathogenic to major tea cultivar Ching-Shin Oolong grown in Taiwan.

Only a few studies have shown the effect of environmental factors on the growth of Diaporthe species. The most recent study was carried out by Arciuolo et al. [51], who tested the optimal temperature and water activity required for mycelial growth, pycnidial conidiomata development, and asexual spore production of D. eres, the causal agent of hazelnut defects. Arciuolo et al. [51] concluded that the optimum temperature for mycelial growth of $D$. eres was observed at $20-25^{\circ} \mathrm{C}$ and at $30^{\circ} \mathrm{C}$ for pycnidia and cirrhi development. In another study, Hilário et al. [12] observed that four novel pathogens of Diaporthe, namely, D. crousii, D. phillipsii, D. rossmaniae, and D. vacuae, causing twig blight and dieback of Vaccinium corymbosum in Portugal had an optimum temperature for mycelial growth at $20-25{ }^{\circ} \mathrm{C}$. The present study provides insights into the effect of environmental factors such as temperature and $\mathrm{pH}$ on the mycelial growth of the Diaporthe strains isolated from $C$. sinensis in Taiwan under a controlled environment. Our results showed that all species identified in this study reached maximum colony diameter at $25-30{ }^{\circ} \mathrm{C}$ and preferred to grow under low acidic to alkaline rather than acidic medium. The observations in the present study are consistent with the results of Arciuolo et al. [51] and Hilário et al. [12]. In the future, these abiotic factors could be used as the basis for developing a predictive model for the infection of Diaporthe taxa of tea plants in Taiwan.

\section{Conclusions}

In conclusion, the research outcomes of the present study improve the understanding of Diaporthe species allied with leaf spots on tea leaves and deliver valuable data for effective disease management of $C$. sinensis in Taiwan. The study identified six Diaporthe species associated with leaf spots on $C$. sinensis in Taiwan tea fields. These species comprise one novel species and three new records in Diaporthe on C. sinensis. However, to gain better knowledge of the diversity, pathogenicity, distribution, and implications of Diaporthe taxa on tea plantations in Taiwan, extensive surveys on C. sinensis plantations and the collection of a larger number of samples should reflect the goals of future studies.

\section{Materials and Methods}

\subsection{Sample Collection, Fungal Isolation, and Morphological Examination}

Tea leaves with characteristic leaf spots were collected from five distinct tea fields located in major tea-growing areas in Taiwan (Figure 1). The samples were collected in resealable plastic bags and carried back to the laboratory. Pure cultures were obtained through a single conidium isolation method, as described in Udayanga et al. [26] and Ariyawansa et al. [4]. In brief, contents of the fruiting body were mounted in a drop of sterile distilled water on a flame-sterilized cavity slide and pipetted to thoroughly mix. The drop of spore suspension was spread evenly on a Petri dish of water agar (WA) and 
incubated at $25^{\circ} \mathrm{C}$ in the dark for $12 \mathrm{~h}$. Single germinating conidia were transferred to a Petri dish of potato dextrose agar (PDA; HiMedia Laboratories Pvt. Ltd., Mumbai, India) and incubated at $25^{\circ} \mathrm{C}$ in the dark. Colonial characterization was carried out from isolates cultured on PDA (HiMedia Laboratories Pvt. Ltd., Mumbai, India). Conidiomatal growth was detected on WA with double-autoclaved pine needles placed on the surface of agar (PNA), corn meal agar (CMA; HiMedia Laboratories Pvt. Ltd., Mumbai, India), or PDA supplemented with $10 \% \mathrm{NaCl}$, which were incubated at $25^{\circ} \mathrm{C}$ under continuous blue light for 7 to 14 days [33]. Microscopic characteristics were examined in distilled water, with 30 measurements taken from each structure using cellSense Standard software (XV Imaging, Version 3.17.0.16686) under an Olympus BX51 microscope (Olympus Corp., Tokyo, Japan) with differential interference contrast (DIC) illumination.

In this study, type specimens were deposited in the herbarium of the Department of Plant Pathology and Microbiology, National Taiwan University (NTUPPMH). Ex-type living cultures were deposited in the Department of Plant Pathology and Microbiology, National Taiwan University Culture Collection (NTUPPMCC), and the Bioresource Collection and Research Centre (BCRC).

\subsection{DNA Extraction, $P C R$, and Sequencing}

The growing mycelia of each isolate were gathered from cultures incubated at $25^{\circ} \mathrm{C}$ in the dark for 7 to 14 days. Genomic DNA were extracted with EasyPure Genomic DNA Spin Kit (Bioman Scientific Co., Ltd., New Taipei, Taiwan) according to the manufacturer's guidelines (Bioman Scientific Co., Ltd., New Taipei, Taiwan). PCR amplifications of ITS, tef1- $\alpha$, tub2, and cal gene regions were separately performed in $25 \mu \mathrm{L}$ reaction mixtures, as described in Ariyawansa et al. [4]. The relevant primer pairs included in this study are in Table 1. The PCR products were visualized by electrophoresis on a $1.5 \%$ agarose gel stained with BioGreenTM Safe DNA Gel buffer (Bioman Scientific Co., Ltd., New Taipei, Taiwan). The sequence purified amplicons from each gene region were obtained using the Sanger sequencing method at the Genomics Co., Ltd., (New Taipei, Taiwan). Newly obtained sequences in the present study were deposited to NCBI GenBank.

Table 1. Gene regions and primer sequences used in this study.

\begin{tabular}{|c|c|c|c|}
\hline Region & Primers & Sequence $\left(5^{\prime} \rightarrow 3^{\prime}\right)$ & Reference \\
\hline ITS & ITS5 & GGA AGT AAA AGT CGT AAC AAG G & [52] \\
\hline tef1- $\alpha$ & $\begin{array}{l}\text { EF1-728F } \\
\text { EF1-986R }\end{array}$ & $\begin{array}{l}\text { CAT CGA GAA GTT CGA GAA GG } \\
\text { TAC TTG AAG GAA CCC TTA CC }\end{array}$ & [53] \\
\hline tub2 & $\begin{array}{l}\text { Bt2a } \\
\text { Bt2b }\end{array}$ & $\begin{array}{c}\text { GGT AAC CAA ATC GGT GCT TTC } \\
\text { ACC CTC AGT GTA GTG ACC CTT GGC }\end{array}$ & [54] \\
\hline $\mathrm{cal}$ & $\begin{array}{l}\text { CAL-228F } \\
\text { CAL-737R }\end{array}$ & $\begin{array}{l}\text { GAG TTC AAG GAG GCC TTC TCC C } \\
\text { CAT CTT TCT GGC CAT GG }\end{array}$ & [53] \\
\hline
\end{tabular}

\subsection{Strain Selection, Sequence Alignment, and Phylogenetic Analysis}

An initial ITS-only tree containing all taxa currently recognized in Diaporthe was made to resolve the clades containing the isolates obtained in this study (data not shown). This analysis was further used to select the species to be included in the multilocus phylogenetic analyses. DNA sequence data of ITS, tef1- $\alpha, t u b 2$, and cal loci were used to determine the phylogenetic placement of isolates. DNA sequences of each strain were searched against GenBank by nucleotide BLAST (BLASTn) to find the nearest matches. Strains in GenBank with 95-99\% similarity to known Diaporthe species together with species previously described as pathogens on tea were included in the phylogenetic analysis following the recent publications of Ariyawansa et al. [4], Yang et al. [55], Dissanayake et al. [31,56], Gao et al. [57], Guarnaccia and Crous [8], and Manawasinghe et al. [13]. The strains used in the present study and their GenBank accession numbers are presented in Table S4. 
Multiple sequence alignments were generated in MAFFT v. $6.864 \mathrm{~b}$ with default parameters (http:/ / mafft.cbrc.jp/alignment/server/index.html, accessed on 3 April 2021). The alignments for each gene were visually improved manually where necessary in MEGA v. 5 [58]. Single gene trees were first built for ITS, tef1- $\alpha, t u b 2$, and cal, and finally subjected to a multilocus analysis. MrModeltest v. 2.3 [59] under the Akaike Information Criterion (AIC) implemented in PAUP v. 4.0b10 [60] was used to determine the individual selection of evolutionary models for phylogenetic analyses of each locus.

Two phylogenetic tree inference methods, maximum likelihood (ML) in RAxML [61], and Bayesian analyses in MrBayes v. 3.0b4 [62] were used to evaluate the phylogenetic relationships of the strains used in this study, as described in Ariyawansa et al. [4] and Tsai et al. [33]. Bootstrap values obtained via ML (MLB) and Bayesian posterior probabilities (BPP) that were equal to or greater than $70 \%$ or greater than 0.95 , respectively, are indicated below or above each node (Figure 2). Topologies of the trees obtained from each gene were visually compared to confirm the similarity between the overall tree topology of the individual datasets and that of the tree obtained from the combined alignment. MEGA v. 5 [58] and FigTree v. 1.4 [63] software were used to assess and visualize phylogenetic trees and data files.

The principles of Genealogical Concordance Phylogenetic Species Recognition (GCPSR) were used to identify the species limits within Diaporthe-like taxa [64,65]. Dettman et al. [65] proposed that species should be differentiated when fulfilling one of the following two criteria: genealogical concordance or genealogical non-discordance. In other words, if clades exist in at least some of the trees, then they are recognized as genealogically concordant; clades are recognized as genealogically non-discordant if they are significantly supported with high statistical values (MLB $\geq 70, \mathrm{PP} \geq 0.95$ ) in a single locus without conflict at or above this support level in any other single-locus trees. By following this criterion, poorly supported non-monophylies in one locus are eliminated without undermining well-supported monophylies in another locus.

Based on the outcomes of the phylogenetic analysis considering a single strain representing each taxon, a total of six isolates were randomly selected for the pathogenicity, mycelial growth, temperature, and $\mathrm{pH}$ tests.

\subsection{Mycelial Growth Test}

In total, six strains representing six taxa identified in this study, NTUPPMCC 18-152-1 (Diaporthe apiculatum), NTUPPMCC 18-055-1 (D. hongkongensis), NTUPPMCC 18-153-1 (D. hsinchuensis), NTUPPMCC 18-154-1 (D. tulliensis), NTUPPMCC 18-157-1 (D. perseae), and NTUPPMCC 18-158-1 (D. passiflorae), were used to determine the radial growth of mycelia. The growth rate was evaluated following a modified procedure of Huang et al. [66]. A $4 \mathrm{~mm}$-diam mycelial disk was cut from the edge of a three-day-old PDA culture, placed centrally into a Petri dish $\left(90 \mathrm{~mm}\right.$ diam) of PDA $(13 \mathrm{~mL})$ and incubated at $25^{\circ} \mathrm{C}$ in the dark for three days. Measurements were taken daily, based on the diameter of two perpendicular axes per fungal colony. The mycelial growth was determined on the final measurement. The test was conducted thrice with three replicates per trial.

\subsection{Temperature and $p H$ Effects on Mycelial Growth}

The same isolates, volume of medium, inoculation method, and standard of measurement used in the mycelial growth test were used to test the effects of temperature and $\mathrm{pH}$. Further details for each assessment are described below.

The effect of temperature on radial mycelial growth was checked on a daily basis and determined on the third day after inoculation at $10,15,20,25,30,35,40$, and $45^{\circ} \mathrm{C}$ in the dark. All single inoculations were conducted on Petri dishes of PDA. The test was performed three times, with three replicates per trial. The present protocol was modified from Keith et al. [67].

The optimal $\mathrm{pH}$ for radial mycelial growth was studied at $\mathrm{pH} 3,4,5,6,7,8,9$, and 10 . PDA plates were heated to mix prior to sterilization, and the $\mathrm{pH}$ values were adjusted with 
$1 \mathrm{M} \mathrm{HCl}$ and $1 \mathrm{M} \mathrm{NaOH}$ solutions $[68,69]$. The tested cultures were incubated at $25{ }^{\circ} \mathrm{C}$ in the dark for three days, and the colony sizes were measured on a daily basis. The test was conducted three times, with three replicates per trial.

\subsection{Pathogenicity Assessment}

The same isolates used in the above temperature and $\mathrm{pH}$ investigations were used in the pathogenicity assessment. The test was conducted on detached tea leaves (picked from fourth to sixth leaf below the apical bud) randomly collected from healthy branches of Ching-Shin Oolong gathered from a conventional tea field (ca. 15 years old) located in Pinglin District, New Taipei City $\left(24^{\circ} 56^{\prime} 26.9^{\prime \prime} \mathrm{N}, 121^{\circ} 43^{\prime} 25.4^{\prime \prime} \mathrm{E}\right)$, as described in Tsai et al. [33]. In brief, fresh leaf-attached tea branches were thoroughly rinsed with tap water to remove dust, and excessive water was gently eliminated with tissue paper. A flat rack $\left(164 \times 114 \times 26 \mathrm{~mm}^{3}\right)$ wrapped with sterile tissue paper was placed in a plastic box $\left(320 \times 240 \times 70 \mathrm{~mm}^{3}\right)$, and the box was filled with $700 \mathrm{~mL}$ of sterilized distilled water. Four tea leaves were detached from the branch, surface sterilized with $75 \%$ ethanol and fixed to the rack at the foliar tip and base with rubber bands. The leaves were wounded by pinpricking with a sterile needle. A $4 \mathrm{~mm}$-diam mycelial disk was cut from the margin of a seven-day-old colony on PDA and inoculated on a single wounded site [70]. In total, four tea leaves inoculated with PDA disks (4 mm diam) without mycelium served as controls. The box with the above contents was sealed with plastic wrap to maintain moisture and incubated at $26 \pm 1{ }^{\circ} \mathrm{C}$ under a $12 / 12 \mathrm{~h}$ photocycle [33]. The pathogenicity was determined after 14 days of incubation. The test was conducted three times, with four replicates for each round per isolate.

\subsection{Statistical Analysis}

The statistical analysis was carried out by one-way analysis of variance (ANOVA) using SAS ${ }^{\circledR}$ University Edition v. 3.8, and the pairwise comparison was performed via Tukey's range test $(\alpha=0.05)$.

Supplementary Materials: The following are available online at https: / www.mdpi.com/article/ 10.3390/plants10071434/s1, Table S1: collection information of Diaporthe taxa used in this study, Table S2: mycelial growth (mm diam., with the origin diameter of inoculated mycelial plug deducted) of each isolate (NTUPPMCC) at every $\mathrm{pH}$ level. Data (mean \pm standard deviation) with the same letters are not significantly different on the basis of Tukey's range test. Table S3: GenBank accession numbers of isolates included in the multilocus sequence analysis, Table S4: mycelial growth (mm diam., with the origin diameter of inoculated mycelial plug deducted) of individual isolate (NTUPPMCC) at each temperature. Data (mean \pm standard deviation) with the same letters are not significantly different on the basis of Tukey's range test.

Author Contributions: Conceptualization, H.A.A.; methodology, I.T. and H.A.A.; investigation, I.T., P.W., M.T. and H.A.A.; data curation, H.A.A., I.T., J.-Y.W., P.W., M.T., S.-R.L., N.S., J.K., A.M.E., R.C.; writing-H.A.A. original draft preparation, I.T. and H.A.A.; writing-review and editing, all authors; funding acquisition, H.A.A., A.M.E. and R.C. All authors have read and agreed to the published version of the manuscript.

Funding: This study was funded by grants from the Higher Education Sprout Projects (grant number: NTUJP-108L7215 and NTUJP-110L7221) and The Researchers Supporting Project number (RSP-2021/56), King Saud University, Riyadh, Saudi Arabia.

Institutional Review Board Statement: Not applicable.

Informed Consent Statement: Not applicable.

Data Availability Statement: Publicly available datasets were analyzed in this study. This data can be found here: https:/ / www.ncbi.nlm.nih.gov / (accessed on 13 July 2021) and https: / / www. mycobank.org/page/Simple\%20names\%20search (accessed on 13 July 2021). 
Acknowledgments: This research work was also partially supported by Chiang Mai University. The authors extend their appreciation to The Researchers supporting project number (RSP-2021/56), King Saud University, Riyadh, Saudi Arabia. We are grateful to C.P. Lin, Parichad Pakdeeniti, Panatda Kankavee, Chia-Yun Yen, Yu-Chen Lin, Vivienne Hsieh-Wu, Chia-Yi Wu, A.D. Ariyawansa, D.M.K. Ariyawansa, Ruwini Ariyawansa, Amila Gunasekara, and Oshen Kemika for their valuable ideas.

Conflicts of Interest: The authors declare no conflict of interest.

\section{References}

1. Udayanga, D.; Castlebury, L.A.; Rossman, A.Y.; Chukeatirote, E.; Hyde, K.D. Insights into the genus Diaporthe: Phylogenetic species delimitation in the D. eres species complex. Fungal Divers. 2014, 67, 203-229. [CrossRef]

2. Yang, Q.; Fan, X.L.; Guarnaccia, V.; Tian, C.M. High diversity of Diaporthe species associated with dieback diseases in China, with twelve new species described. MycoKeys 2018, 39, 97-149. [CrossRef] [PubMed]

3. Gao, Y.; Liu, F.; Cai, L. Unravelling Diaporthe species associated with Camellia. Syst. Biodivers. 2016, 14, 102-117. [CrossRef]

4. Ariyawansa, H.A.; Tsai, I.; Withee, P.; Tanjira, M.; Yen, C.Y.; Al-Rashed, S.; Elgorban, A.M.; Cheewangkoon, R. Diaporthe taiwanensis: A new taxon causing leaf spots and necrosis on Ixora chinensis in Taiwan. Phytotaxa 2020, 461, 155-165. [CrossRef]

5. Udayanga, D.; Castlebury, L.A.; Rossman, A.Y.; Chukeatirote, E.; Hyde, K.D. The Diaporthe sojae species complex: Phylogenetic re-assessment of pathogens associated with soybean, cucurbits and other field crops. Fungal Biol. 2015, 119, 383-407. [CrossRef]

6. Mondal, S.N.; Vicent, A.; Reis, R.F.; Timmer, L.W. Efficacy of pre-and postinoculation application of fungicides to expanding young citrus leaves for control of melanose, scab, and Alternaria brown spot. Plant Dis. 2007, 91, 1600-1606. [CrossRef]

7. Udayanga, D.; Castlebury, L.A.; Rossman, A.Y.; Hyde, K.D. Species limits in Diaporthe: Molecular re-assessment of D. citri, D. cytosporella, D. foeniculina and D. rudis. Persoonia 2014, 32, 83-101. [CrossRef]

8. Guarnaccia, V.; Crous, P.W. Emerging citrus diseases in Europe caused by species of Diaporthe. IMA Fungus 2017, 8, 317-334. [CrossRef]

9. Guarnaccia, V.; Crous, P.W. Species of Diaporthe on Camellia and Citrus in the Azores Islands. Phytopathol. Mediterr. 2018, 57, 307-319. [CrossRef]

10. Chaisiri, C.; Liu, X.Y.; Lin, Y.; Li, J.B.; Xiong, B.; Luo, C.X. Phylogenetic analysis and development of molecular tool for detection of Diaporthe citri causing melanose disease of citrus. Plants 2020, 9, 329. [CrossRef] [PubMed]

11. Allan-Perkins, E.; Li, D.W.; Schultes, N.; Yavuz, S.; LaMondia, J. The identification of a new species, Diaporthe humulicola, a pathogen causing Diaporthe leaf spot on common hop. Plant Dis. 2020, 104, 2377-2390. [CrossRef]

12. Hilário, S.; Amaral, I.A.; Gonçalves, M.F.; Lopes, A.; Santos, L.; Alves, A. Diaporthe species associated with twig blight and dieback of Vaccinium corymbosum in Portugal, with description of four new species. Mycologia 2020, 112, 293-308. [CrossRef]

13. Manawasinghe, I.S.; Dissanayake, A.J.; Li, X.; Liu, M.; Wanasinghe, D.N.; Xu, J.; Zhao, W.; Zhang, W.; Zhou, Y.; Hyde, K.D.; et al. High genetic diversity and species complexity of Diaporthe associated with grapevine dieback in China. Front. Microbiol. 2019, 10, 1936. [CrossRef]

14. Li, D.; Zhang, H.; Song, Q.; Liu, J.; Yang, Q.; Luan, F.; Li, D. First report of Diaporthe eres causing branch canker on Cinnamomum camphora (camphor tree) in Jiangxi Province, China. Plant Dis. 2021. [CrossRef]

15. Guo, Y.S.; Crous, P.W.; Bai, Q.; Fu, M.; Yang, M.M.; Wang, X.H.; Du, Y.M.; Hong, N.; Xu, W.X.; Wang, G.P. High diversity of Diaporthe species associated with pear shoot canker in China. Persoonia 2020, 45, 132-162. [CrossRef]

16. Muntanola-Cvetkovic, M.; Mihaljcevic, M.; Petrov, M. On the identity of the causative agent of a serious Phomopsis-Diaporthe disease in sunflower plant. Nova Hedwig. 1981, 34, 417-435.

17. Thompson, S.M.; Tan, Y.P.; Young, A.J.; Neate, S.M.; Aitken, E.A.B.; Shivas, R.G. Stem cankers on sunflower (Helianthus annuus) in Australia reveal a complex of pathogenic Diaporthe (Phomopsis) species. Persoonia 2011, 27, 80-89. [CrossRef] [PubMed]

18. Díaz, G.A.; Latorre, B.A.; Lolas, M.; Ferrada, E.; Naranjo, P.; Zoffoli, J.P. Identification and characterization of Diaporthe ambigua, D. australafricana, D. novem, and D. rudis causing a postharvest fruit rot in kiwifruit. Plant Dis. 2017, 101, 1402-1410. [CrossRef]

19. Garcia-Reyne, A.; López-Medrano, F.; Morales, J.M.; Garcia-Esteban, C.; Martin, I.; Eraña, I.; Meije, Y.; Lalueza, A.; AlastrueyIzquierdo, A.; Rodríguez-Tudela, J.L.; et al. Cutaneous infection by Phomopsis longicolla in a renal transplant recipient from Guinea: First report of human infection by this fungus. Transpl. Infect. Dis. 2011, 13, 204-207. [CrossRef]

20. Mostert, L.; Crous, P.W.; Kang, J.C.; Phillips, A.J. Species of Phomopsis and a Libertella sp. occurring on grapevines with specific reference to South Africa: Morphological, cultural, molecular and pathological characterization. Mycologia 2001, 93, $146-167$. [CrossRef]

21. Mostert, L.; Kang, J.C.; Crous, P.W.; Denman, S. Phomopsis saccharata sp. nov., causing a canker and die-back disease of Protea repens in South Africa. Sydowia 2001, 53, 227-235.

22. Muralli, T.S.; Suryanarayanan, T.S.; Geeta, R. Endophytic Phomopsis species: Host range and implications for diversity estimates. Can. J. Microbiol. 2006, 52, 673-680. [CrossRef]

23. Rehner, S.A.; Uecker, F.A. Nuclear ribosomal internal transcribed spacer phylogeny and host diversity in the coelomycete Phomopsis. Can. J. Bot. 1994, 72, 1666-1674. [CrossRef]

24. Santos, J.M.; Vrandečić, K.; Ćosić, J.; Duvnjak, T.; Phillips, A.J.L. Resolving the Diaporthe species occurring on soybean in Croatia. Persoonia 2011, 27, 9-19. [CrossRef] [PubMed] 
25. Udayanga, D.; Liu, X.; McKenzie, E.H.; Chukeatirote, E.; Bahkali, A.H.; Hyde, K.D. The genus Phomopsis: Biology, applications, species concepts and names of common phytopathogens. Fungal Divers. 2011, 50, 189. [CrossRef]

26. Udayanga, D.; Liu, X.; Crous, P.W.; McKenzie, E.H.; Chukeatirote, E.; Hyde, K.D. A multi-locus phylogenetic evaluation of Diaporthe (Phomopsis). Fungal Divers. 2012, 56, 157-171. [CrossRef]

27. Van Rensburg, J.C.J.; Lamprecht, S.C.; Groenewald, J.Z.; Castlebury, L.A.; Crous, P.W. Characterisation of Phomopsis spp. associated with die-back of rooibos (Aspalathus linearis) in South Africa. Stud. Mycol. 2006, 55, 65-74. [CrossRef] [PubMed]

28. Rossman, A.Y.; Adams, G.C.; Cannon, P.F.; Castlebury, L.A.; Crous, P.W.; Gryzenhout, M.; Jaklitsch, W.M.; Mejia, L.C.; Stoykov, D.; Udayanga, D.; et al. Recommendations of generic names in Diaporthales competing for protection or use. IMA Fungus 2015, 6 , 145-154. [CrossRef]

29. Gomes, R.R.; Glienke, C.; Videira, S.I.R.; Lombard, L.; Groenewald, J.Z.; Crous, P.W. Diaporthe: A genus of endophytic, saprobic and plant pathogenic fungi. Persoonia 2013, 31, 1-41. [CrossRef]

30. Dong, Z.; Manawasinghe, I.S.; Huang, Y.; Shu, Y.; Phillips, A.J.L.; Dissanayake, A.J.; Hyde, K.D.; Xiang, M.; Luo, M. Endophytic Diaporthe associated with Citrus grandis cv Tomentosa in China. Front. Microbiol. 2021, 11, 3621. [CrossRef]

31. Dissanayake, A.J.; Camporesi, E.; Hyde, K.D.; Wei, Z.; Yan, J.Y.; Li, X.H. Molecular phylogenetic analysis reveals seven new Diaporthe species from Italy. Mycosphere 2017, 8, 853-877. [CrossRef]

32. Ariyawansa, H.A.; Tsai, I.; Thambugala, K.M.; Chuang, W.Y.; Lin, S.R.; Hozzein, W.N.; Cheewangkoon, R. Species diversity of Pleosporalean taxa associated with Camellia sinensis (L.) Kuntze in Taiwan. Sci. Rep. 2020, 10, 12762. [CrossRef]

33. Tsai, I.; Chung, C.L.; Lin, S.R.; Hung, T.H.; Shen, T.L.; Hu, C.Y.; Hozzein, W.N.; Ariyawansa, H.A. Cryptic diversity, molecular systematics, and pathogenicity of genus Pestalotiopsis and allied genera causing gray blight disease of tea in Taiwan, with a description of a new Pseudopestalotiopsis species. Plant Dis. 2021, 105, 425-443. [CrossRef]

34. Dissanayake, A.J.; Chen, Y.Y.; Liu, J.K.J. Unravelling Diaporthe species associated with woody hosts from karst formations (Guizhou) in China. J. Fungi 2020, 6, 251. [CrossRef]

35. Guarnaccia, V.; Groenewald, J.Z.; Woodhall, J.; Armengol, J.; Cinelli, T.; Eichmeier, A.; Ezra, D.; Fontaine, F.; Gramaje, D.; Gutierrez-Aguirregabiria, A.; et al. Diaporthe diversity and pathogenicity revealed from a broad survey of grapevine diseases in Europe. Persoonia 2018, 40, 135-153. [CrossRef] [PubMed]

36. Long, H.; Zhang, Q.; Hao, Y.Y.; Shao, X.Q.; Wei, X.X.; Hyde, K.D.; Wang, Y.; Zhao, D.G. Diaporthe species in south-western China. MycoKeys 2019, 57, 113-127. [CrossRef] [PubMed]

37. Crous, P.W.; Summerell, B.A.; Shivas, R.G.; Burgess, T.I.; Decock, C.A.; Dreyer, L.L.; Granke, L.L.; Guest, D.I.; Hardy, G.S.J.; Hausbeck, M.K.; et al. Fungal planet description sheets: 107-127. Persoonia 2012, 28, 138-182. [CrossRef] [PubMed]

38. Senanayake, I.C.; Crous, P.W.; Groenewald, J.Z.; Maharachchikumbura, S.S.; Jeewon, R.; Phillips, A.J.; Bhat, J.D.; Perera, R.H.; Li, Q.R.; Li, W.J.; et al. Families of Diaporthales based on morphological and phylogenetic evidence. Stud. Mycol. 2017, 86, 217-296. [CrossRef]

39. Tzean, S.S.; Tzeng, K.C.; Chang, C.A.; Tsay, T.T.; Yen, S.F. List of Plant Diseases in Taiwan; Bureau of Animal and Plant Health Inspection and Quarantine, Council of Agriculture, Executive Yuan: Taipei, Taiwan, 2019.

40. Farr, D.F.; Rossman, A.Y. Fungal Databases, U.S. National Fungus Collections, ARS, USDA. Available online: https://nt.ars-grin. gov/fungaldatabases / (accessed on 13 June 2021).

41. Dissanayake, A.J.; Liu, M.; Zhang, W.; Chen, Z.; Udayanga, D.; Chukeatirote, E.; Li, X.; Yan, J.; Hyde, K.D. Morphological and molecular characterisation of Diaporthe species associated with grapevine trunk disease in China. Fungal Biol. 2015, 119, 283-294. [CrossRef]

42. Zhang, Z.; Zhang, Z.B.; Huang, Y.T.; Wang, F.; Hu, W.H.; Dai, L.Y.; Zhong, J.; Liu, Y.; Zhu, J.Z. First report of Diaporthe hongkongensis causing fruit rot on peach (Prunus persica) in China. Plant Dis. 2021. [CrossRef]

43. Erper, I.; Turkkan, M.; Ozean, M.; Luongo, L.; Belisario, A. Characterization of Diaporthe hongkongensis species causing stem-end rot on kiwifruit in Turkey. J. Plant Pathol. 2017, 99, 779-782.

44. Kee, Y.J.; Wong, K.L.; Zakaria, L.; Mohd, M.H. Diaporthe species causing stem gray blight of red-fleshed dragon fruit (Hylocereus polyrhizus) in Malaysia. Sci. Rep. 2021, 11, 3907. [CrossRef]

45. Li, H.; Yu, S.; Tang, W.; Miao, M.; Liu, Y. First report of Diaporthe passiflorae and Diaporthe nobilis causing a postharvest kiwifruit rot in Sichuan province, China. Plant Dis. 2019, 103, 771. [CrossRef]

46. Lim, L.; Mohd, M.H.; Zakaria, L. Identification and pathogenicity of Diaporthe species associated with stem-end rot of mango (Mangifera indica L.). Eur. J. Plant Pathol. 2019, 155, 687-696. [CrossRef]

47. Bai, Q.; Wang, G.P.; Hong, N.; Guo, Y.S.; Fu, M. First report of Diaporthe tulliensis and Diaporthe actinidiae causing kiwifruit stem canker in Hubei and Anhui provinces, China. Plant Dis. 2017, 101, 508-509. [CrossRef]

48. Gong, J.L.; Lu, Y.; Wu, W.H.; He, C.P.; Liang, Y.Q.; Huang, X.; Zheng, J.L.; Xi, J.G.; Tang, S.B.; Yi, K.X. First report of Phomopsis heveicola (anamorph of Diaporthe tulliensis) causing leaf blight of coffee (Coffea arabica) in China. Plant Dis. 2020, 104, 570. [CrossRef]

49. Huang, C.C.; Liu, H.H.; Wu, P.H.; Chang, H.X. First report of leaf spot caused by Diaporthe tulliensis on Boston ivy (Parthenocissus tricuspidata) in Taiwan. Plant Dis. 2021. [CrossRef]

50. Chen, K.L.; Kirschner, R. Fungi from leaves of lotus (Nelumbo nucifera). Mycol. Prog. 2018, 17, 275-293. [CrossRef]

51. Arciuolo, R.; Camardo Leggieri, M.; Chiusa, G.; Castello, G.; Genova, G.; Spigolon, N.; Battilani, P. Ecology of Diaporthe eres, the causal agent of hazelnut defects. PLoS ONE 2021, 16, e0247563. [CrossRef] 
52. White, T.J.; Bruns, T.; Lee, S.; Taylor, J. Amplification and Direct Sequencing of Fungal Ribosomal RNA Genes for Phylogenetics. In PCR Protocols: A Guide to Methods and Applications; Innis, M.A., Gelfand, D.H., Sninsky, J.J., White, T.J., Eds.; Academic Press: San Diego, CA, USA, 1990; pp. 315-322.

53. Carbone, I.; Kohn, L.M. A method for designing primer sets for speciation studies in filamentous ascomycetes. Mycologia 1999, 91, 553-556. [CrossRef]

54. Glass, N.L.; Donaldson, G.C. Development of primer sets designed for use with the PCR to amplify conserved genes from filamentous ascomycetes. Appl. Environ. Microbiol. 1995, 61, 1323-1330. [CrossRef]

55. Yang, Q.; Jiang, N.; Tian, C.M. Three new Diaporthe species from Shaanxi Province, China. MycoKeys 2020, 67, 1-18. [CrossRef]

56. Dissanayake, A.J.; Phillips, A.J.L.; Hyde, K.D.; Yan, J.Y.; Li, X.H. The current status of species in Diaporthe. Mycosphere 2017, 8, 1106-1156. [CrossRef]

57. Gao, Y.; Liu, F.; Duan, W.; Crous, P.W.; Cai, L. Diaporthe is paraphyletic. IMA Fungus 2017, 8, 153-187. [CrossRef] [PubMed]

58. Tamura, K.; Peterson, D.; Peterson, N.; Stecher, G.; Nei, M.; Kumar, S. MEGA5: Molecular evolutionary genetics analysis using maximum likelihood, evolutionary distance, and maximum parsimony methods. Mol. Biol. Evol. 2011, 28, 2731-2739. [CrossRef] [PubMed]

59. Nylander, J. MrModeltest v2. Program; Distributed by the Author; Evolutionary Biology Centre, Uppsala University: Uppsala, Sweden, 2004.

60. Swofford, D.L. PAUP*: Phylogenetic Analysis Using Parsimony (and Other Methods), Version 4.0b10; Sinauer Associates: Sunderland, MA, USA, 2002.

61. Silvestro, D.; Michalak, I. RaxmlGUI: A graphical front-end for RAxML. Org. Divers. Evol. 2012, 12, 335-337. [CrossRef]

62. Ronquist, F.; Huelsenbeck, J.P. MrBayes 3: Bayesian phylogenetic inference under mixed models. Bioinformatics 2003, 19, 1572-1574. [CrossRef]

63. Rambaut, A.; Drummond, A. FigTree: Tree Figure Drawing Tool, Version 1.2.2; Institute of Evolutionary Biology, University of Edinburgh: Edinburgh, Scotland, 2008.

64. Taylor, J.W.; Jacobson, D.J.; Kroken, S.; Kasuga, T.; Geiser, D.M.; Hibbett, D.S.; Fisher, M.C. Phylogenetic species recognition and species concepts in fungi. Fungal Genet. Biol. 2000, 31, 21-32. [CrossRef]

65. Dettman, J.R.; Jacobson, D.J.; Turner, E.; Pringle, A.; Taylor, J.W. Reproductive isolation and phylogenetic divergence in Neurospora: Comparing methods of species recognition in a model eukaryote. Evolution 2003, 57, 2721-2741. [CrossRef]

66. Huang, F.; Hou, X.; Dewdney, M.M.; Fu, Y.; Chen, G.; Hyde, K.D.; Li, H. Diaporthe species occurring on citrus in China. Fungal Divers. 2013, 61, 237-250. [CrossRef]

67. Keith, L.M.; Velasquez, M.E.; Zee, F.T. Identification and characterization of Pestalotiopsis spp. causing scab disease of guava, Psidium guajava, in Hawaii. Plant Dis. 2006, 90, 16-23. [CrossRef] [PubMed]

68. Abubakar, A.; Suberu, H.A.; Bello, I.M.; Abdulkadir, R.; Daudu, O.A.; Lateef, A.A. Effect of pH on mycelial growth and sporulation of Aspergillus parasiticus. J. Plant Sci. 2013, 1, 64-67. [CrossRef]

69. Saha, A.; Mandal, P.; Dasgupta, S.; Saha, D. Influence of culture media and environmental factors on mycelial growth and sporulation of Lasiodiplodia theobromae (Pat.) Griffon and Maubl. J. Environ. Biol. 2008, 29, 407-410.

70. Wang, Y.; Xiong, F.; Lu, Q.; Hao, X.; Zheng, M.; Wang, L.; Li, N.; Ding, C.; Wang, X.; Yang, Y. Diversity of Pestalotiopsis-like species causing gray blight disease of tea plants (Camellia sinensis) in China, including two novel Pestalotiopsis species, and analysis of their pathogenicity. Plant Dis. 2019, 103, 2548-2558. [CrossRef] [PubMed] 